\title{
A Protein Binding Specifically to the IgG2b Switch Region
}

\author{
HEINER VÖLK* ${ }^{*}$ and MATTHIAS WABL \\ Department of Microbiology and Immunology, University of California, San Francisco, 94143-0670
}

(Received 20 August 1996; Revised 2 October 1996)

\begin{abstract}
The Abelson-virus-transformed mouse pre-B-cell line 18-81 switches almost exclusively from $\mu$ to $\gamma 2 \mathrm{~b}$. From nuclear extracts of this cell line, we have isolated a factor that specifically binds to $S_{\gamma 2 \mathrm{~b}}$. After an eight-step purification scheme, in which different types of DNA-affinity chromatography were used as key elements, we obtained a preparation with two narrowly spaced bands at approximately $69 \mathrm{kD}$ on a silver-stained SDS gel. Binding specificity of main-peak fractions of affinity-purified proteins was analyzed by gel shift assays, in which $\mathrm{S}_{\gamma_{2 b}}$, but not $\mathrm{S}_{\mu}$, competes. The results are consistent with this factor being part of the switch recombinase.
\end{abstract}

Keywords: Immunoglobulin, class switch, nuclear extracts, affinity chromatography, gel shifts, switch recombinase

\section{INTRODUCTION}

The earliest antibodies produced during the course of an immune response are of the class IgM. As the response proceeds, antibodies with the same specificity of other classes are produced and IgM production declines. This heavy- (H-) chain class switch is not a population phenomenon; a committed B cell that produces an IgM antibody can switch to the production of another class of immunoglobulin (Wabl et al., 1978). The molecular basis of the $\mathrm{H}$-chain class switch is the deletion of a stretch of DNA from $5^{\prime}$ of $\mathrm{C}_{\mu}$ to $5^{\prime}$ of the $\mathrm{C}_{\mathrm{H}}$ gene segment to be expressed (Honjo and Kataoka, 1978; Jäck et al., 1988; Iwasato et al., 1990; von Schwedler et al., 1990). The deletion results from a genetic exchange, with the deleted material being excised as a circular DNA molecule, the so-called switch circle (Jäck et al., 1988; Iwasato et al., 1990; von Schwedler et al., 1990; Harriman et al., 1993). Most recombination break points lie within the so-called switch (S) regions. These are repetitive DNA sequences $5^{\prime}$ of all $\mathrm{C}_{\mathrm{H}}$ gene segments except $C_{\delta}$ (Shimizu and Honjo, 1984). Their overall length $(1-10 \mathrm{~kb})$, as well as the length of their repeat units, is variable. However, all switch regions share some homology. By using $S_{\mu}$ as reference sequence, the degree of homology decreases in the following order: $S_{\mu}>S_{\varepsilon}>S_{\alpha}>S_{\gamma 3}>S_{\gamma 1}>S_{\gamma 2 b}>S_{\gamma 2 a}$ (Nikaido et al., 1982; Stanton and Marcu, 1982).

Little is known about the switch recombinase, the putative enzyme-mediating switch recombination. However, such an enzyme complex must perform the three basic functions of binding, cutting, and ligating. In a current model of class switching, the future $\mathrm{C}_{\mathrm{H}}$ gene segment is targeted by transcription and/or demethylation (reviewed in Lin et al., 1992; Siebenkotten and Radbruch, 1995; Stavnezer, 1996). This is thought to be mediated by vari-

\footnotetext{
*Current address: MRC Cell Mutation Unit

University of Sussex BNI9RR U.K.
} 
ous cytokines produced by $\mathrm{T}$ cells (reviewed in Finkelman et al., 1990). Recombination of $S$ regions would then proceed, possibly mediated by the normal recombination and repair machinery. Indeed, evidence has accumulated that so-called germ-line transcripts are necessary for switch recombination (Lennon and Perry, 1985; Stavnezer-Nordgren and Sirlin, 1986; reviewed in Lin et al., 1992; Lorenz et al., 1995). But other loci are being transcribed as well, so switch recombination needs to be restricted to $\mathrm{S}$ regions; that is, the transcripts themselves may take part in the reaction (Lorenz et al., 1995), or their translation product (Bachl et al., 1996).

Recombination of an isolated (Borggrefe et al., 1996) or transfected (Daniels and Lieber, 1995) switch substrate now can be assayed in vitro, and this has revealed a dependence of the switch recombination on transcription (Daniels and Lieber, 1995). There has been some progress in defining consensus recognition sites by analysis of DNA sequences around recombination break points (Wuerffel et al., 1992; Chou and Morrison, 1993; Kenter et al., 1993), but a more extensive analysis has failed to find such a sequence (Dunnick et al., 1993). In the last few years, there have been reports of several factors that bind to various switch regions, and sometimes to other loci as well, in humans and mice (Wuerffel et al., 1990; Schultz et al., 1991; Xu et al., 1992; Fukita et al., 1993; Mizuta et al., 1993; Kenter et al., 1993). To our knowledge, no function in switch recombination has been shown for these proteins. To date, only the genes encoding a factor that binds single-stranded DNA related to $S_{\mu}$ have been cloned from mouse and humans (Fukita et al., 1993; Mizuta et al., 1993). Two other polypeptides were shown to be transcription factors with targets located also outside of switch regions (Waters et al., 1989; Barberis et al., 1990; Schultz et al., 1991; Williams and Maizels, 1991; Liao et al., 1992; Williams et al., 1993; Brys and Maizels, 1994; Liao et al., 1994; Neurath et al., 1994).

We have assumed that specificity during switch recombination is not entirely determined by cytokine specificity, that is, that specificity is also conferred by factors that bind to $\mathrm{S}$ regions. Nontransformed pre-B cells do not seem to switch at all. Nevertheless, all mouse Abelson-virus transformed pre-B cells switch almost exclusively from $\mu$ to $\gamma 2 \mathrm{~b}$ (Burrows et al., 1981, 1983; Alt et al., 1982; Akira et al., 1983). If our assumption is correct, nuclear extracts from such transformed cells ought to contain factors that predominantly recognize $S \gamma 2 b$. Here we describe the isolation of one such factor.

\section{RESULTS AND DISCUSSION}

Proteins binding to $S_{\gamma_{2 b}}$ were purified from nuclear extracts of the Abelson-virus transformed mouse cell line 18-81. Gel shift assays and silver-stained SDS gels were used to screen the fractions at each stage of purification.

\section{Purification and Gel Shift Assays}

Nuclear extracts $(200 \mathrm{mg}$ ) were loaded onto a 106-ml DEAE fast-flow Sepharose column, eluted with a 400$\mathrm{ml}$ linear gradient from 100 to $200 \mathrm{mM} \mathrm{NaCl}$, followed by an additional $200 \mathrm{mM}$ wash. On the basis of a gel shift analysis (Fig. 1), fractions 36-96 eluting at 111-195 $\mathrm{mM}$ and containing $10.8 \mathrm{mg}$ protein were

A. 12345678910111213141516171819

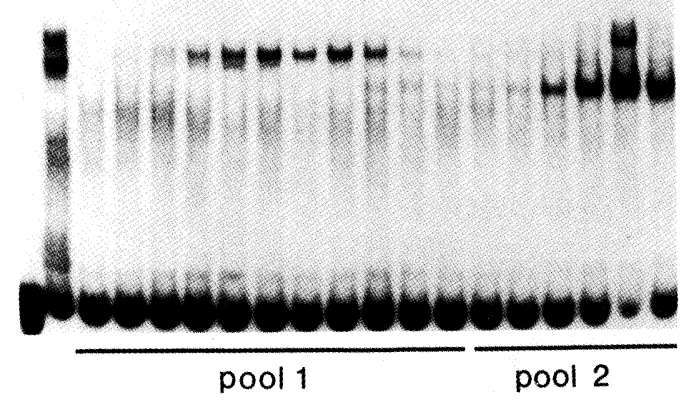

B. 123456789101112131415161718

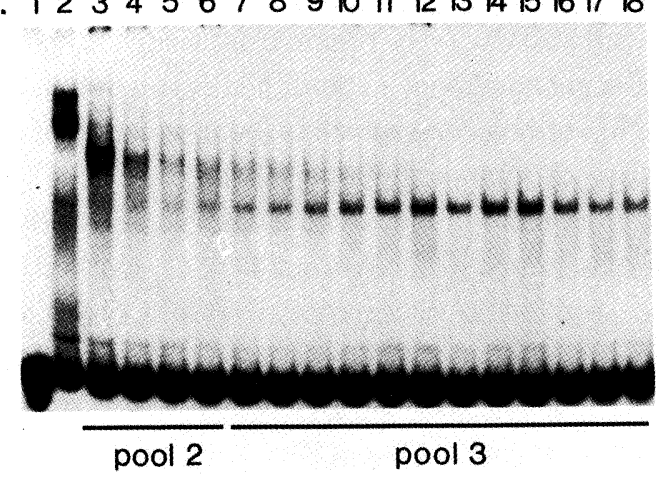

FIGURE 1 Autoradiograms of gel shift assays with eluates from the 106-ml DEAE column. Every fourth fraction was probed with a $57-$ bp $\mathrm{S}_{\gamma \mathrm{b}}$ fragment. In each gel, lane 1 had no protein; lane 2 had 13.4 $\mu \mathrm{g}$ crude nuclear extract. (A) Lanes 3-19: Fractions 54-118. (B) Lanes 3-18: Fractions 122-182. Fractions 36-96 (pool 1) were processed further. 
pooled, diluted to $100 \mathrm{mM} \mathrm{NaCl}$, and passed over a 50 ml BioRex 70 column. Bound material was released with a linear 300-ml 100-1000 mM linear gradient followed by a $2 \mathrm{M} \mathrm{NaCl}$ wash. Fractions $16-40$ eluting at $100-310 \mathrm{mM} \mathrm{NaCl}$ and containing $1.1-\mathrm{mg}$ protein $(\mathrm{NaCl})$ were pooled, concentrated on a 1-ml DEAE column, and loaded in $50 \mathrm{mM} \mathrm{NaCl}$ onto a Streptavidin-agarose- $\mathrm{S}_{\gamma 2 \mathrm{~b}}$-DNA column (SAS). After elution with $250 \mathrm{mM} \mathrm{NaCl}$ and adjustment of pooled active fractions to the proper loading conditions, the material was passed a second time over the SAS column under the same conditions. Pooled active fractions were adjusted to $50 \mathrm{mM} \mathrm{NaCl}$ and applied to a third affinity column, which was eluted in steps of 100, 150, 200, and $250 \mathrm{mM} \mathrm{NaCl}$. The 100 - and $150-\mathrm{mM}$ eluates contained different gel shift activities, which were well separated from each other (not shown); only the former was studied further. Silver-stained SDS gels of the 100 $\mathrm{mM} \mathrm{NaCl}$ fractions are shown in Fig. 2.

Active samples from $100 \mathrm{mM} \mathrm{NaCl}$ eluates were pooled, diluted to $50 \mathrm{mM}$, and applied to a fourth SAS column, which was successively eluted with buffer containing 65,75 , and $100 \mathrm{mM} \mathrm{NaCl}$. Silver-stained SDS

$$
+++t
$$
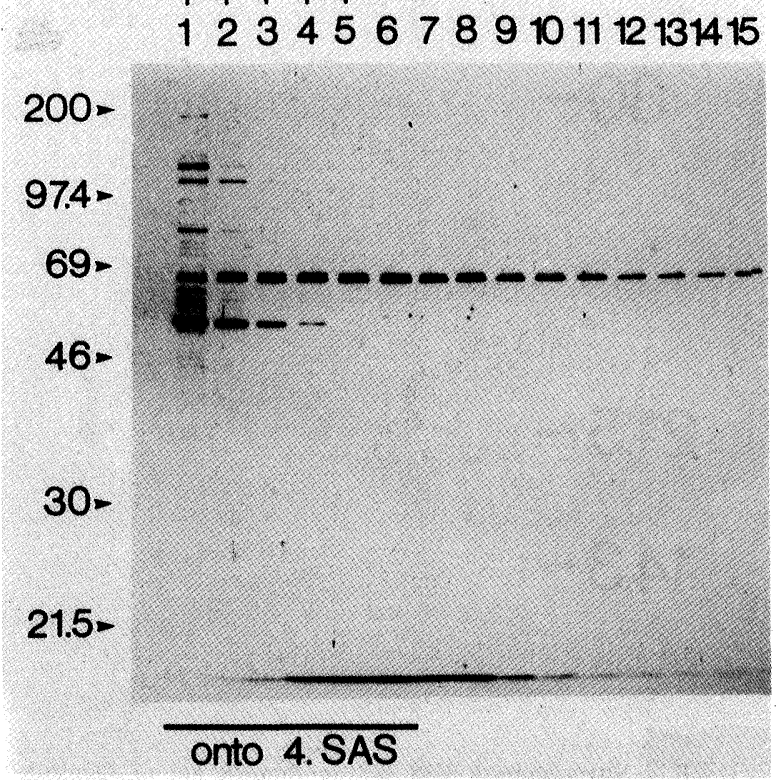

FIGURE 2 Silver-stained gels of eluates from the third affinity column. Aliquots of $30 \mu \mathrm{l}$ were analyzed under reducing conditions. Molecular weight standards $(\mathrm{kD})$ are indicated on the left. Lanes 1-15: Fractions 14-42 (100 mM NaCl). + : Shift activity. gels are shown in Fig. 3. DNA-binding activity was detectable in the first two steps only after concentration. In the $100 \mathrm{mM} \mathrm{NaCl}$ eluates, the activity peak was maximal at fractions 76-78. The activity decreased rapidly toward the inactive fraction 70 and much more slowly toward the inactive fraction 96. There were few proteins left in the shift-positive fractions, which we will call "SAS-purified" fractions hereafter. The major band is about $69 \mathrm{kD}$.

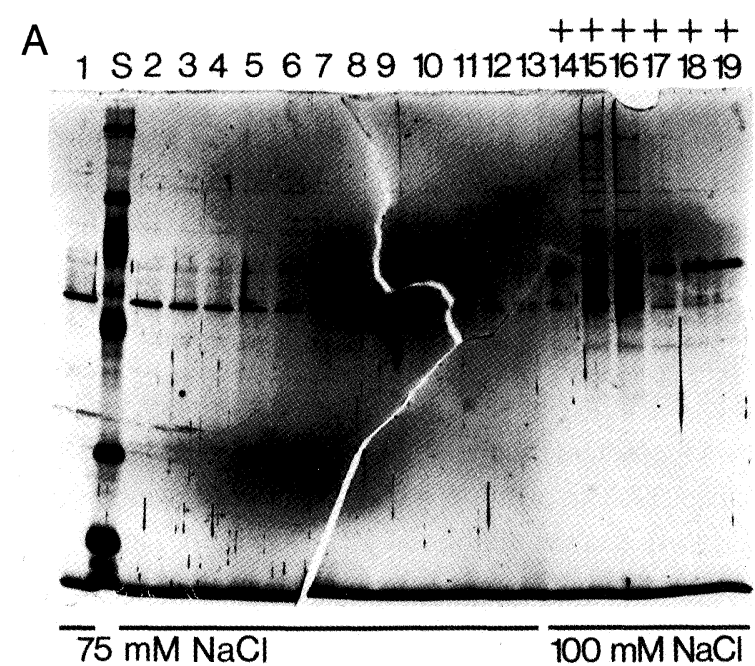

$\mathrm{B}_{++}+++$

$$
12 S 345678910111213141516171819
$$

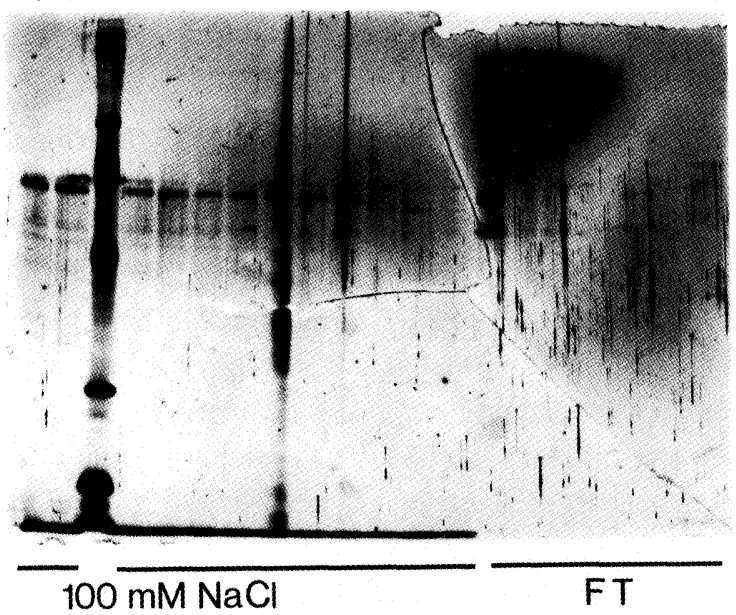

FIGURE 3 Silver-stained gels of SAS-purified fractions. Aliquots of $30 \mu \mathrm{l}$ were analyzed under reducing conditions. Even fractions were tested. (A) Lanes 1-13: Fractions 46-70 $(75 \mathrm{mM} \mathrm{NaCl})$. Lanes 14-19: Fractions 72-82 (100 mM NaCl). (B) Lanes 1-12: Fractions 84-106 (100 mM NaCl). Lanes 13-19: Flowthrough fractions 8, 12-32. + : Shift activity. 


\section{Molecular-Weight Determination after Dynabead Separation}

To confirm that the $69-\mathrm{kD}$ protein is indeed the major binding component in these fractions, we ran an SDS gel with Dynabead-purified material. Dynabeads are paramagnetic particles embedded in polystyrene spheres and can be easily removed from a suspension by means of a strong magnet. Beads to which genomic $S_{\gamma 2 b}$ had been coupled were incubated with SAS-purified fractions $83-88$ and ca. $2 \%(v / v)$ of 73-74. Bound material was eluted with basic buffer containing $300 \mathrm{mM}$ $\mathrm{NaCl}$. In pilot experiments, $300 \mathrm{mM} \mathrm{NaCl}$ was shown to inhibit gel shifts with the 245-bp $S_{\gamma 2 b}$ probe. Control Dynabeads without DNA were treated identically. Aliquots were analyzed again by reducing SDS-PAGE and silver staining (Fig. 4). Supernatant from beads without $S_{\gamma 2 b}$ DNA had two narrow-spaced weak bands of ca. $69 \mathrm{kD}$ (Fig. 4, lane 2), which were not visible in the supernatant incubated with DNA-coated beads (Fig. 4 , lane 1). The eluate of the $S_{\gamma 2 b}$ beads showed a strong narrowly spaced doublet at $69 \mathrm{kD}$ (Fig. 4, lane 3). Although difficult to see on a print, where they appear as a single band, it was easily visible on the original gel that

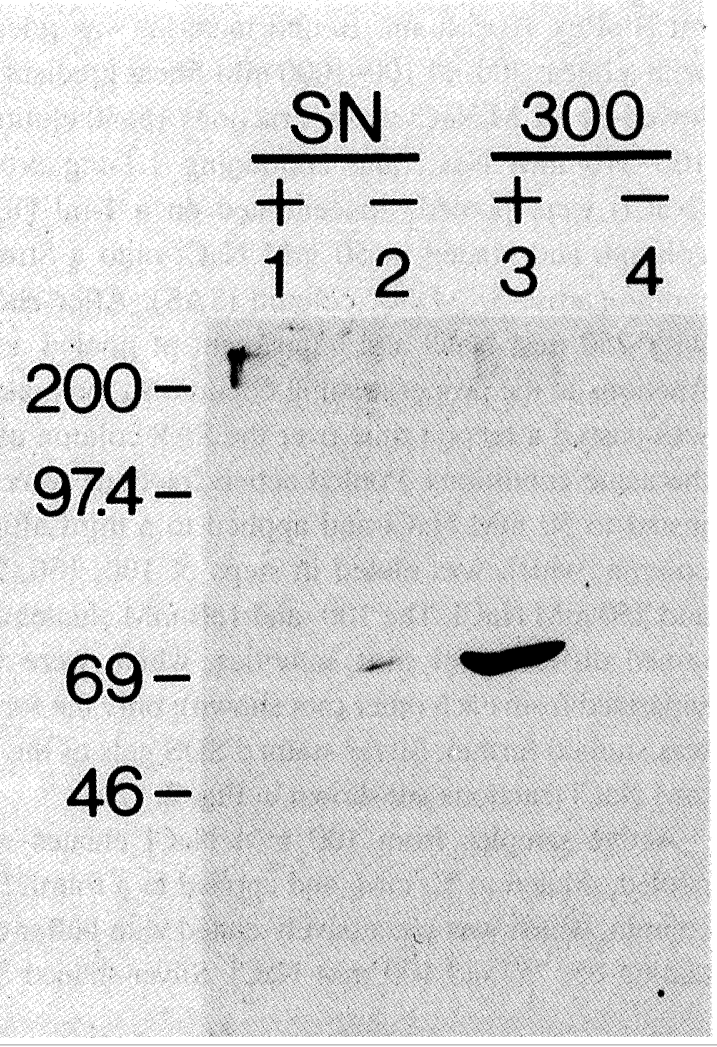



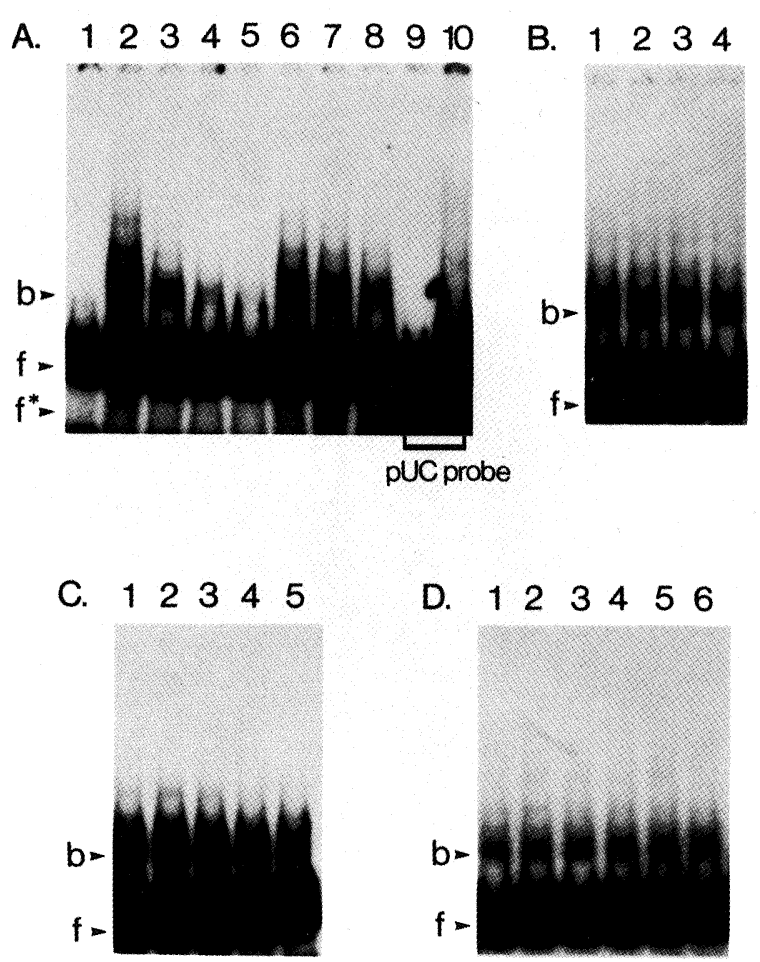

FIGURE 5 Autoradiograms of competition gel shift assays with SAS-purified protein. Unless stated otherwise, the labeled probe was 245-bp S ${ }_{22 b}$ DNA. (A) Lane 1: No protein. Lane 2: Protein but no competitor. Lanes 3-5: 2.75, 5.5, 11 ng cold 245-bp $\mathrm{S}_{\gamma \mathrm{b} b}$ DNA. Lanes 6-8: 2.75, 5.5, $11 \mathrm{ng}$ cold 196-bp pUC DNA. Lane 9: 196-bp labeled pUC probe without protein. Lane 10: 196-bp labeled pUC probe with protein. (B) Lanes 1-4: 5.5, 11, 22, $44 \mathrm{ng}$ cold pdIdC. (C) Lanes 1-5: 2.75, 5.5, 11, 22, 44 ng cold double-stranded PhiX 174 fragments. (D) Lanes 1-6: 4, 8, 12, 16, 20, 24 ng cold 1.3-kb $\mathrm{S}_{\mu}$. B: Double-stranded 245-bp $S_{22 b}$ probe bound to protein. f: Free doublestranded 245-bp $S_{\gamma 2 b}$ probe. $f^{*}$ : Free double-standed 196-bp pUC probe. vs. $2.75 \mathrm{ng}$ ). Competition by the pUC piece was somewhat puzzling, especially because when the same pUC fragment was used as a labeled probe, almost no binding activity was detectable (Fig. 5A, lanes 9 and 10). There is some, albeit quite limited, homology between $\mathrm{S}_{\gamma 2 \mathrm{~b}}$ and pUC sequences (Table 1):

In another experiment with the 245-bp $S_{\gamma 2 b}$ probe in $80 \mathrm{mM} \mathrm{NaCl}$, up to $18 \mathrm{ng}$ of five 57-bp DNAs in combination with 12-ng pdIdC were used. $\mathrm{S}_{\gamma 2 \mathrm{~b}}, \mathrm{~S}_{\alpha}, \mathrm{S}_{\mu}$, and $\mathrm{NF} \kappa \mathrm{B}$ consensus sequences did not compete, nor did part of $\mathrm{a} \mathrm{C}_{\mu}$ exon (not shown).

We also tested binding of the $69-\mathrm{kD}$ complex to single-stranded DNA. The 245-bp $\mathrm{S}_{\gamma 2 \mathrm{~b}}$ probe was heat-denatured and incubated with protein from fractions 76-77 of the fourth SAS. Little, if any, protein/singlestranded DNA complex was detected (Fig. 6, Lane 2).

To exclude a possible formation of bands by binding of protein to residual nucleotides from labeling reactions, radioactive dCTP or ddATP was incubated with fractionated material in the presence or absence of unlabeled DNA. None of the samples showed any trace of complex formation (not shown).

SAS-purified fractions 74,79 , and 80 were used for DNase I footprinting. Only one very small site was protected at positions $237-238$ (CC) of the bottom strand (Fig. 7, lanes 1 and 2). Because the flanking positions were insensitive to DNase I cleavage, even without added fraction material (Fig. 7, lane 1), the actual contact site most likely stretches from positions 236 to 240 (TCCCA). Two other sites with the TCCCA motif were found within the 245-bp $\mathrm{S}_{\gamma 2 \mathrm{~b}}$ probe (Table 1), but no protection could be demonstrated under the conditions tested. However, their neighboring sequences showed some diversity, and some of these surrounding bases

TABLE I Comparison of Footprint Sequence (TCCCA) and Flanking Sequences with Similar Motifs and Their Flanking Sequences without DNase I Protection

\begin{tabular}{|c|c|c|c|c|c|}
\hline DNA & Position $^{\mathrm{a}}$ & Footprint $^{\mathrm{b}}$ & Sequence of the th & he top strand & \\
\hline 196-bp pUC & B $6-30$ & ND & GCGCA ACTGT & TGGGA AGGGC & GATCG \\
\hline 196-bp pUC & T 52-76 & ND & ACGTC GTGAC & TGGGA AAACC & CTGGC \\
\hline 57-bp $S_{\gamma 2 b}$ & B 29-53 & ND & CTGGG GAWGG & TRGGA RTRTG & ACGCG \\
\hline $245-\mathrm{bp} \mathrm{S} S_{\gamma 2 \mathrm{~b}}$ & B $22-46$ & - & CAGGG ATAGG & TGGGA GTATT & AGGGA \\
\hline 245-bp $S_{\gamma 2 b}$ & B $120-144$ & - & CTGGG GCAGG & TGGGA GTGTG & AGGGA \\
\hline $245-b p S_{\gamma 2 b}$ & B $226-245^{c}$ & + & GGTAG GAATG & TGGGA GACCA & GATCC \\
\hline
\end{tabular}

" T/B: Top/Bottom strand has the motif. Positions always refer to the sequence of the top strand.

${ }^{\mathrm{h}} \mathrm{ND}$ : Not determined.

' The last $5 \mathrm{bp}$ of the flanking sequence at the $3^{\prime}$ end are part of the pUC multiple cloning site. 


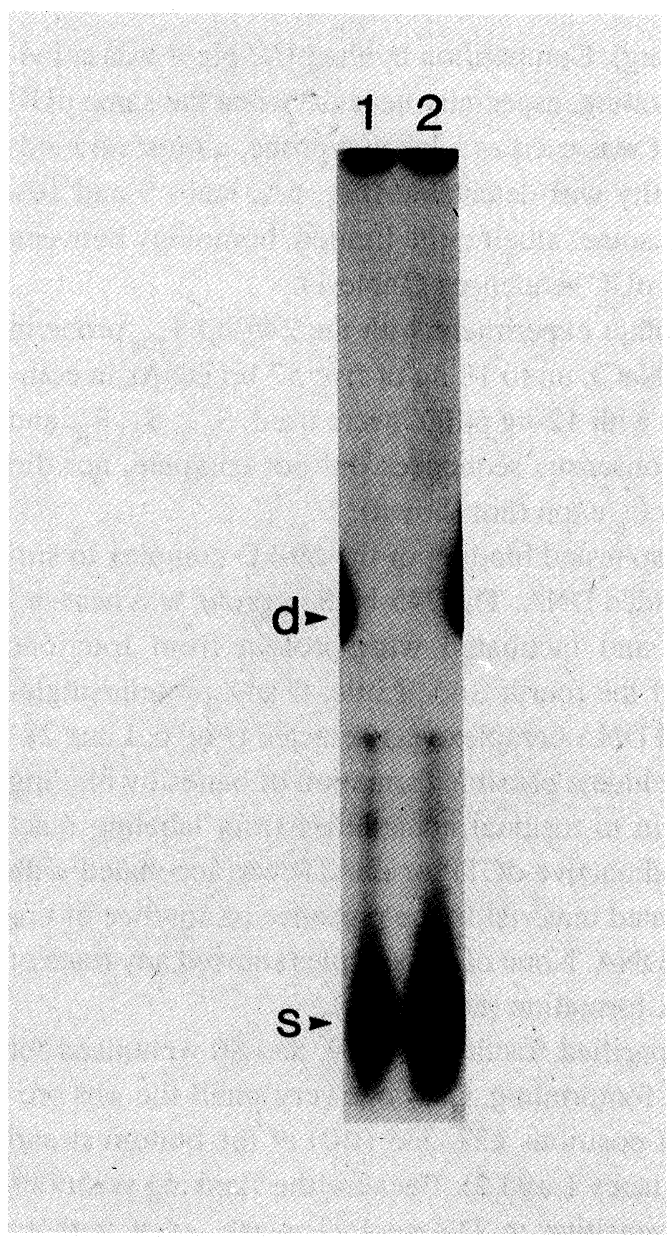

FIGURE 6 Autoradiogram of gel shift analysis with single-stranded DNA. The 245-bp $S_{\text {pb }}$ probe was heat-denatured and subsequently incubated in $100 \mathrm{mM} \mathrm{NaCl}$ buffer without (lane 1) or with (lane 2) material from SAS-purified fractions 76-77. s: Free single-standed DNA probe. d: Position where the free double-stranded probe would run.

could have an effect on directing DNA-binding proteins to the one but not the other site. Another reason of why there was no large footprint or no other visible footprints could have been the decreased binding of purified proteins in the presence of divalent cations. But calcium and magnesium ions need to be added to the binding mix together with DNase I in order to promote the nicking reaction. It may be that very high concentrations of purified protein will be necessary to reach a reasonable balance.

Using the data on competition with the pUC fragment, and assuming the 5-bp stretch as the complete and only site in the probe, one can estimate the competitiveness ratio of specific to nonspecific DNA in the gel shift

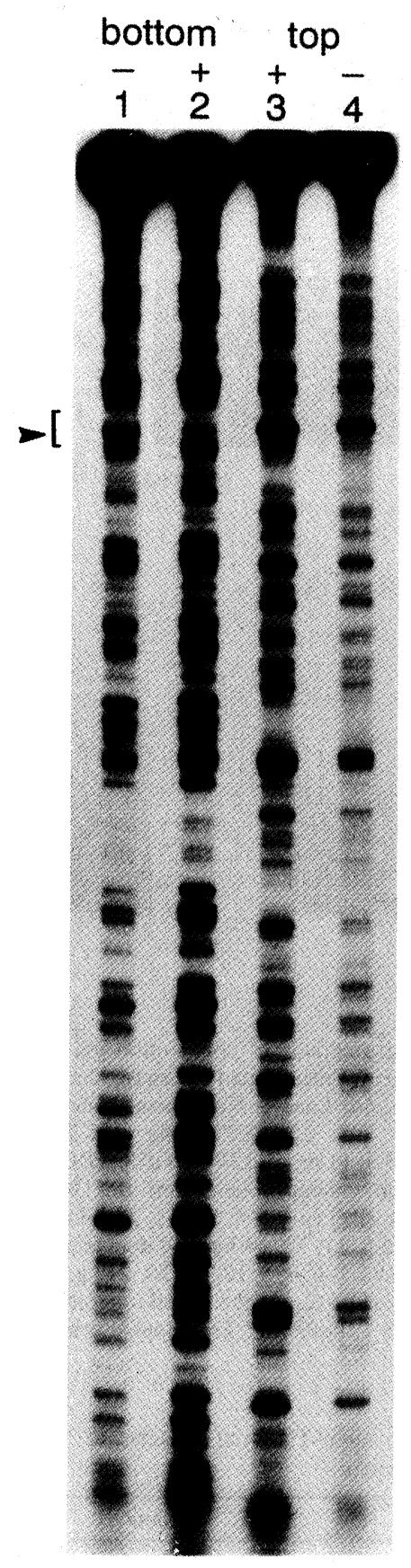

FIGURE 7 Autoradiogram of a DNase I footprinting experiment with subsequent denaturing polyacrylamide gel electrophoresis: Lanes 1 and 2: Bottom strand. Lanes 3 and 4: Top strand. Positions refer to the complementary sequence on the top strand. Samples were incubated with (lanes 2 and 3) or without (lanes 1 and 4) SASpurified protein. Subsequent denaturing electrophoresis was done for $4 \mathrm{hr}$. The arrowhead indicates protection at positions $237-238$ (CC) of the bottom strand. 
assays to be 110 . That is, the specific 5-bp motif is 110 times as good a competitor as nonspecific DNA.

\section{Does Our 69-kD Factor Correspond to a Published One?}

Kenter et al. (1993) described sites for two factors called SNAP and SNIP/NFkB, which bind to sites A and $\mathrm{B}$, respectively. These sites can be found in the switch regions $S_{\gamma 3}, S_{\gamma 1}$, and $S_{\gamma 2 b}$. The 245-bp $S_{\gamma 2 b}$ probe used in our experiments has three potential 15bp spanning A sites at positions $8-22,57-71$, and 204-218. There is only one mismatch, which is located within the first site. SNAP, of unknown molecular weight, is very $\mathrm{pH}$-sensitive and does not seem to bind to DNA above $150 \mathrm{mM} \mathrm{NaCl}$. This seems to distinguish it from the 69-kD factor, although $\mathrm{pH}$ dependence and salt concentrations for elutions are difficult to compare. Attempts to identify SNAP activity in cell line 18-81 were not successful (Amy Kenter, personal communication). For the $69-\mathrm{kD}$ factor reported here, binding at $\mathrm{pH} 7.4$ was only little less than binding at $\mathrm{pH}$ 7.9. In addition, our protein-DNA complexes were shown to be more stable in salt; they disappear only between 250 and $300 \mathrm{mM} \mathrm{NaCl}$. Finally, the DNase I protected positions were 236-240, a region well separated from the nearest possible A site at positions 204-218. Thus, our 69-kD protein does not seem to be SNAP.

The B site, which is recognized by NFKB, spans 11 bp. Based on competition gel shifts and a supershift induced by polyclonal anti-p50 serum, it was proposed that NFKB is involved in binding to various switch regions. NFKB consists of a p50 and p65 subunit with molecular weights of 50 and $65 \mathrm{kD}$, respectively. Heterodimers consisting of p50 and p65, as well as p50 homodimers, can bind to DNA (Urban et al., 1991). The $S_{\gamma 2 b}$ probe used in our experiments has two potential B sites at positions 42-52 and 140-150 (one mismatch each). However, there are several reasons why we think the purified shift activities from our work are different from NFKB. In competition gel shift assays, a 57-bp DNA containing three complete NFKB sites should have been a very strong competitor, but it did not compete. The 196-bp pUC fragment contains one complete $\mathrm{NF \kappa B}$ site, but used as a probe, it hardly bound anything. Further, our footprinting experiments show a protected site at position 236-240, which is far away from the two potential B sites at positions $42-52$ and 140-150. Thus, our 69$\mathrm{kD}$ protein does not seem to be SNIP/NFKB. Nor is it likely that it is the LR-1 factor, which has been described to be a 106-kD protein (Williams et al., 1993).

We conclude that the $69-\mathrm{kD}$ factor that specifically binds to $S_{\gamma 2 b}$ is likely to be a novel protein.

\section{MATERIALS AND METHODS}

\section{Nuclear Extracts}

Cells of the Abelson-virus-transformed mouse pre-Bcell line 18-81 were grown to 0.5 to $2 \times 10^{6} / \mathrm{ml}$. Nuclear extracts $(200 \mathrm{mg})$ were prepared from $26 \mathrm{l}$ of cells according to Ausubel et al. (1987) with the following modifications: All buffers contained $1 \mathrm{mM}$ PMSF, 1 $\mu \mathrm{g} / \mathrm{ml}$ Leupeptin, Pepstatin, and Aprotinin. Hypotonic buffer for swelling as well as all subsequently used buffers were supplemented with $0.1 \%$ NP- 40 . The final $\mathrm{NaCl}$ concentration during the 45-min extraction was $405 \mathrm{mM}$. Before freezing, samples were adjusted to $100 \mathrm{mM} \mathrm{NaCl}$ and $20 \%$ glycerol by dilution rather than by dialysis.

\section{Column Chromatography}

All steps were performed at $4^{\circ} \mathrm{C}$. The basic buffer was 20 mM HEPES, pH 7.9, 20\% glycerol, 1 mM DTT, 0.1 mM EDTA, $1 \mathrm{mM}$ PMSF, as well as $1 \mu \mathrm{g} / \mathrm{ml} \mathrm{E-64,} \mathrm{Le-}$ upeptin, Pepstatin, and Aprotinin. Flowthrough, washes, and eluted fractions were screened for DNA-binding activity by gel shift assays. Determination of protein concentrations was done with Bradford assays.

To prepare the SAS affinity column, $5.1 \mathrm{ml} \mathrm{Strepta-}$ vidin agarose was washed with $2 \mathrm{M} \mathrm{NaCl}, \mathrm{TE}, 0.1 \%$ NP-40 followed by PBS. Biotinylated (double-stranded) 57-bp $\mathrm{S}_{\gamma 2 \mathrm{~b}}$ DNA $(300 \mu \mathrm{g})$ in $3 \mathrm{ml}$ fill-in mix with $0.1 \%$ NP- 40 was passed over the column four times before washing with PBS, $0.1 \%$ NP-40, 1 mM EDTA followed by $2 \mathrm{M} \mathrm{NaCl}$, TE, $0.1 \% \mathrm{NP}-40$, then $100 \mathrm{mM}$ 
$\mathrm{NaCl}, \mathrm{TE}$ at $\mathrm{pH}$ 8.0. An equilibration step was performed with basic buffer supplemented with $50 \mathrm{mM}$ $\mathrm{NaCl}, \mathrm{NP}-40, \mathrm{BSA}$, DTT, and Bestatin. Before loading, samples were adjusted to $50 \mathrm{mM} \mathrm{NaCl}, 0.1 \% \mathrm{NP}-40$, $0.1 \mathrm{mg} / \mathrm{ml} \mathrm{BSA}$, and $40 \mu \mathrm{g} / \mathrm{ml}$ Bestatin, unless otherwise specified. Washes and elution were performed without BSA. Bound material was eluted with step gradients.

\section{Purification with Dynabeads Coupled to Genomic $S_{\gamma 2 b}$ DNA}

The 3.7-kb insert of the plasmid p245 was released by digest with the restriction enzymes Eco RI and Hin dIII. Biotinylation of the Eco RI end was accomplished by partial Sequenase fill-in with dATP and Biotin-16ddUTP. DNA $(72 \mu \mathrm{g})$ was coupled to $1 \mathrm{ml}$ of Dynabeads suspension $\left(6-7 \times 10^{8} / \mathrm{ml}\right)$ in TE, $1 \mathrm{M} \mathrm{NaCl}$ for $2 \mathrm{hr}$. Before and after coupling, beads were washed extensively with the same buffer used for immobilization of the DNA. Ca. $1.4 \mathrm{ml} \mathrm{SAS-purified} \mathrm{protein,}$ mostly fractions $83-88$ and only about $2 \%(v / v) 73-74$, were incubated with the beads for $7 \mathrm{hr}$ on ice with occasional agitation. Elution was performed for $20 \mathrm{~min}$ on ice with $120 \mu \mathrm{l}$ basic buffer containing $300 \mathrm{mM}$ $\mathrm{NaCl}$.

\section{Gel Shift Assays}

The gel shift assay was modified from Strauss and Varshavsky (1984). Protein was incubated with $10,000 \mathrm{cpm}$ of $3^{\prime}$ end-labeled probe and various amounts of pdIdC for $20 \mathrm{~min}$ at RT. The final volume was $20 \mu \mathrm{l}$ in $20 \mathrm{mM}$ HEPES $\mathrm{pH} 7.9,10-14 \%$ glycerol, $1 \mathrm{mM}$ DTT, and $100 \mathrm{mM} \mathrm{NaCl}$. Samples were electrophoresed for $10 \mathrm{~min}$ at $200 \mathrm{~V}$ at RT through a $4 \%$ TAE polyacrylamide gel and then at $180 \mathrm{~V}$ for $1.5-2.5 \mathrm{hr}$ at $4^{\circ} \mathrm{C}$.

\section{DNAs and DNA Sequencing}

\section{Plasmids}

$\mathrm{pUC} / \mathrm{S} \mu$ (A), a gift from Richard Scheuermann (Dallas), is a derivative of pUC 19 with the $3.5-\mathrm{kb}$ Xba I fragment $5^{\prime}$ to the $\mathrm{C}_{\mu}$ exons (Stanton and Marcu, 1982). The insert with the switch $\mu$ region was modified with linkers and cloned into the Cla I site. $\mathrm{pS}_{\gamma 2 \mathrm{~b}}$ is a pUC 19 with the insert of the plasmid pSL1 (Lang et al., 1982) with a ca. 400-bp deletion at the $3^{\prime}$ end of the insert. p245 is a pUC 19 containing the 245-bp Bgl II subfragment from the $\mathrm{pS}_{\gamma 2 \mathrm{~b}}$ insert cloned into the Bam HI site.

\section{7-mer Primer mcs1 17-mer Primer mes2 57-mer $S_{\gamma 2 b}$ (Nikaido et al., 1982) \\ 57-mer $\mathbf{S}_{\boldsymbol{\alpha}}$ (Nikaido et al., 1982) \\ 57-mer $\mathbf{S}_{\boldsymbol{\mu}}$ (Nikaido et al. 1982) \\ 57-mer NF $\kappa$ B (Urban et al., 1991) \\ 57-mer $\mathbf{C}_{\boldsymbol{\mu}}$}

CGAGCTCGGTACCCGGG TGCATGCCTGCAGGTCG GGGACCAGWCCTAGCAGCTPTGGGGGAGCTGGGGAWGGTPGGAPTPTGACGCGATTA ATGAGCTGGGATGAGCTGAGCTAGGCTGGAATAGGCTGGGCTGGGCTGGCGCGATTA GAGCTGAGCTGGGGTGAGCTGAGCTGAGCTGGGGTGAGCTGAGCTGAGCCGCGATTA GAGGGGACTTTCCGAGAGAGGGGACTTTCCGAGAGAGGGGACTTTCCGACGCGATTA GGGACTTCCTGCCCAGCACCATTTCTTCACCTGGAACTACCAGAACAACCGCGATTA (Schreier et al., 1986)

8-mer Primer. (Bio)-TAatcGCG synthesized with Biotin-ON phosphoramidite (Clontech). pdIdC. 1.2-1.4 kb average length (Pharmacia).

PhiX 174 RF (Sanger et al., 1978).

DNase I Footprinting and AG Chemical Sequencing. These were done according to Ausubel et al. (1987). Strand scission was done in $10 \mu 1100 \mathrm{mM} \mathrm{NaOH}, 1 \mathrm{mM}$ EDTA for $30 \mathrm{~min}$ at $90^{\circ} \mathrm{C}$. After precipitation, samples were run on a $6 \%, 7 \mathrm{M}$ urea sequencing gel. 


\section{Acknowledgements}

This work was supported by NIH grant RO1 GM37699 and by funds of the Markey Trust, and by fellowships of the Fonds der Chemischen Industrie and the Daimler-Benz Foundation to H.V. Most of the material here is taken from H.V.'s doctoral thesis submitted to the University of Kaiserslautern, Germany.

\section{References}

Akira, S., Sugiyama, H., Yoshida, N., Kikutani, H., Yamamura, Y. and Kishimoto, T. (1983) Isotype switching in murine pre-B cell lines. Cell, 34, 545-556.

Alt, F. W., Rosenberg, N., Casanova, R. J., Thomas, E. and Baltimore, D. (1982) Immuno-globulin heavy-chain expression and class switching in a murine leukemia cell line. Nature, 296, 325-331.

Ausubel, F. M., Brent, R., Kingston, R. E., Moore, D. D., Smith, J. A., Seidman, J. G. and Struhl, K. (1987) In Current Protocols in Molecular Biology (New York: Greene Publishing and John Wiley), Interscience.

Bachl, J., Turck, C. W. and Wabl, M. (1996) Translatable immunoglobulin germ line transcript. Eur. J. Immunol., 26, 870-874.

Barberis, A., Widenhorn, K., Vitelli, L. and Busslinger, M. (1990) A novel B-cell lineage-specific transcription factor present at early but not late stages of differentiation. Genes Dev., 4, 849-859.

Brys, A. and Maizels, N. (1994) LR1 regulates $c$-myc transcription in B-cell lymphomas. Proc. Natl. Acad. Sci. USA, 91, 4915-4919.

Burrows, P. D., Beck, G. B. and Wabl, M. R. (1981) Expression of $\mu$ and $\gamma$ immunoglobulin heavy chains in different cells of a cloned mouse lymphoid line. Proc. Natl. Acad. Sci. USA, 78, 564-568.

Burrows, P. D., Beck-Engeser, G. B. and Wabl, M. R. (1983) Immunoglobulin heavy-chain class switching in a pre-B cell line is accompanied by DNA rearrangement. Nature, 306, 243-246.

Chou, C. L. and Morrison, S. L. (1993) A common sequence motif near nonhomologous recombination breakpoints involving Ig sequences. J. Immunol., 150, 5350-5360.

Daniels, G. A. and Lieber, M. R. (1995) Strand specificity in the transcriptional targeting of recombination at immunoglobulin switch sequences. Proc. Natl. Acad. Sci. USA, 92, 5625-5629.

Dunnick, W., Hertz, G. Z., Scappino, L. and Gritzmacher, C. (1993) DNA sequences at immunoglobulin switch region recombination sites. Nucleic Acids Res., 21, 365-372.

Finkelman, F. D., Holmes, J., Katona, I. M., Urban, J. F., Beckmann, M. P., Park, L. S., Schooley, K. A., Coffman, R. L., Mosmann, T. R. and Paul, W. E. (1990) Lymphokine control of in vivo immunoglobulin isotype selection. Annu. Rev. Immunol., 8, 303-333.

Fukita, Y., Mizuta, T. R., Shirozu, M., Ozawa, K., Shimizu, A. and Honjo, T. (1993) The human S $\mu b p-2$, a DNA-binding protein specific to the single-stranded guanine-rich sequence related to the immunoglobulin $\mu$ chain switch region. J. Biol. Chem., 268, 17463-17470.

Harriman, W., Volk, H., Defranoux, N. and Wabl, M. (1993) Immunoglobulin class switch recombination. Annu. Rev. Immunol., 11, 361-384.

Honjo, T. and Kataoka, T. (1978) Organization of immunoglobulin heavy chain genes and allelic deletion model. Proc. Natl. Acad. Sci. USA, 75, 2140-2144.
Iwasato, T., Shimizu, A., Honjo, T. and Yamagishi, H. (1990) Circular DNA is excised by immunoglobulin class switch recombination. Cell, 62, 143-149.

Jäck, H. M., McDowell, M., Steinberg, C. M. and Wabl, M. (1988) Looping out and deletion mechanism for the immunoglobulin heavy-chain class switch. Proc. Natl. Acad. Sci. USA, 85, 1581-1585.

Kenter, A. L., Wuerffel, R., Sen, R., Jamieson, C. E. and Merkulov, G. V. (1993) Switch recombination breakpoints occur at nonrandom positions in the $\mathrm{S}_{\gamma}$ tandem repeat. J. Immunol., 151, $4718-4731$.

Lang, R. B., Stanton, L. W. and Marcu, K. B. (1982) On immunoglobulin heavy chain class switching: Two $\gamma 2 \mathrm{~b}$ genes are rearranged via switch sequences in MPC-11 cells but only one is expressed. Nucleic Acids Res., 10, 611-630.

Lennon, G. G. and Perry, R. P. (1985) $\mathrm{C}_{\mu}$-containing transcripts initiate heterogeneously within the IgH enhancer region and contain a novel 5 non-translatable exon. Nature, 318, 475-478.

Lin, Y. C., Shockett, P. and Stavnezer, J. (1992) Regulation of transcription of the germline immunoglobulin alpha constant region gene. Curr. Top. Microbiol. Immunol., 182, 157-165.

Liao, F., Birshtein, B., Busslinger, M. and Rothman, P. (1994) The transcription factor BSAP (NF-HB) is essential for immunoglobulin germ-line transcription. J. Immunol., 152, 2904-2917.

Liao, F., Giannini, S. L. and Birshtein, B. K. (1992) A nuclear DNA-binding protein expressed during early stages of $B$ cell differentiation interacts with diverse segments within and $3{ }^{\circ}$ of the IgH chain gene cluster. J. Immunol., 148, 2909-2917.

Lorenz, M., Jung, S. and Radbruch, A. (1995) Switch transcripts in immunoglobulin class switching. Science 267, 1825-1828.

Mizuta, T. R., Fukita, Y., Miyoshi, T., Shimizu, A. and Honjo, T. (1993) Isolation of cDNA encoding a binding protein specific to 5 -phosphorylated single-stranded DNA with G-rich sequences. Nucleic Acids Res., 21, 1761-1766.

Neurath M. F., Strober, W. and Wakatsuki, Y. (1994) The murine Ig 3 $\alpha$ enhancer is a target site with repressor function for the B cell lineage-specific transcription factor BSAP (NF-HB, S $\alpha$ BP). J. Immunol., 153, 730-742.

Nikaido, T., Yamawaki-Kataoka, Y. and Honjo, T. (1982) Nucleotide sequences of switch regions of immunoglobulin $C \varepsilon$ and $\mathrm{C} \gamma$ genes and their comparison. J. Biol. Chem., 257, 7322-7329.

Sanger, F., Coulson, A. R., Friedmann, T., Air, G. M., Barrell, B. G., Brown, N. L., Fiddes, J. C., Hutchison, C. A., Slocombe, P. M. and Smith, M. (1978) The nucleotide sequence of bacteriophage phi X 174. J. Mol. Biol., 125, 225-246.

Schreier, P. H., Quester, S. and Bothwell, A. (1986) Allotypic differences in murine $\mu$ genes. Nucliec Acids Res., 14, 2381-2389.

Schultz, C. L., Elenich, L. A. and Dunnick, W. A. (1991) Nuclear protein binding to octamer motifs in the immunoglobulin $\gamma 1$ switch region. Int. Immunol., 3, 109-116.

Shimizu, A. and Honjo, T. (1984). Immunoglobulin class switching. Cell 36, 801-803.

Siebenkotten, G. and Radbruch, A. (1995). Towards a molecular understanding of immunoglobulin class switching. The Immunologist, 3, 141-145.

Stanton, L. W. and Marcu, K. B. (1982) Nucleotide sequence and properties of the murine $\gamma 3$ immunoglobulin heavy chain switch region: Implications for successive $\mathrm{C}_{\gamma}$ gene switching. Nucleic Acids Res., 10, 5993-6006.

Stavnezer, J. (1996). Immunoglobulin class switching. Curr. Opin. Immunol., 8, 199-205.

Stavnezer-Nordgren, J. and Sirlin, S. (1986) Specificity of immunoglobulin heavy chain switch correlates with activity of 
germline heavy chain genes prior to switching. EMBO J., 5, 95-102.

Strauss, F. and Varshavsky, A. (1984). A protein binds to a satellite DNA repeat at three specific sites that would be brought into mutual proximity by DNA folding in the nucleosome. Cell, 37, 889-901.

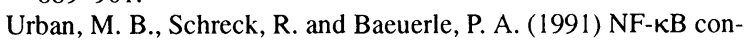
tacts DNA by a heterodimer of the p50 and p65 subunit. $E M B O$ J., 10, 1817-1825.

von Schwedler, U., Jäck, H. M. and Wabl, M. (1990) Circular DNA is a product of the immunoglobulin class switch. Nature, 345, $452-454$.

Wabl, M. R., Forni, L. and Loor, F. (1978). Switch in immunoglobulin class production observed in single clones of committed lymphocytes. Science, 199, 1078-1080.

Waters, S. H., Saikh, K. U. and Stavnezer, J. (1989) A B-cell-specific nuclear protein that binds to DNA sites 5 to immunoglobulin $\mathrm{S}_{\alpha}$ tandem repeats is regulated during differentiation. Mol. Cell. Biol., 9, 5594-5601.
Williams, M. and Maizels, N. (1991). LR1, a lipopolysaccharideresponsive factor with binding sites in the immunoglobulin switch regions and heavy-chain enhancer. Genes Dev., 5, 2353-2361.

Williams, M., Hanakahi, L. A. and Maizels, N. (1993). Purification and properties of LR1, an inducible DNA binding protein from mammalian B lymphocytes. J. Biol. Chem. 268, 13731-13737.

Wuerffel, R. A., Asher, T. N. and Kenter, A. L. (1990). Detection of an immunoglobulin switch region-specific DNA-binding protein in mitogen-stimulated mouse splenic B cells. Mol. Cell. Biol. 10, $1714-1718$.

Wuerffel, R., Jamieson, C. E., Morgan, L., Merkulov, G. V., Sen, R. and Kenter, A. L. (1992) Switch recombination breakpoints are strictly correlated with DNA recognition motifs for immunoglobulin $\mathrm{S}_{\gamma_{3}}$ DNA-binding proteins. J. Exp. Med., 176, 339-349.

Xu, L., Kim, M. G. and Marcu, K. B. (1992) Properties of B cell stage specific and ubiquitous nuclear factors binding to immunoglobulin heavy chain gene switch region. Int. Immunol. $4,875-887$. 


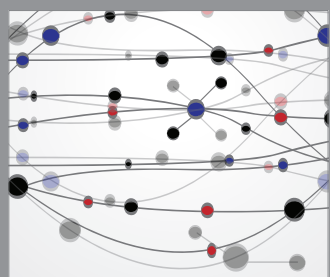

The Scientific World Journal
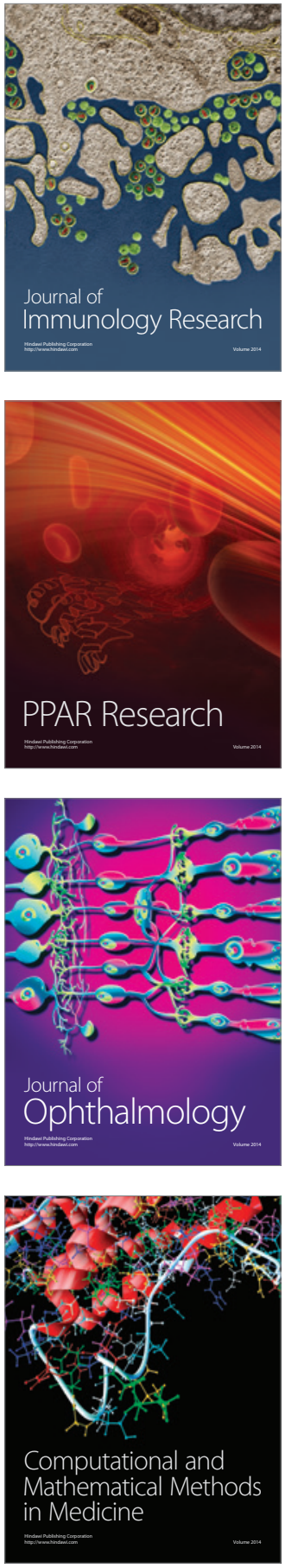

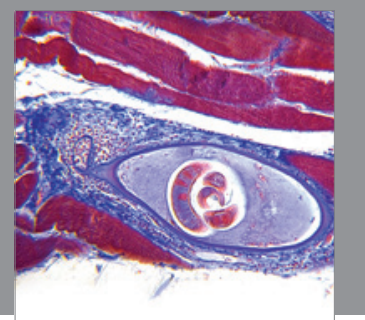

Gastroenterology

Research and Practice
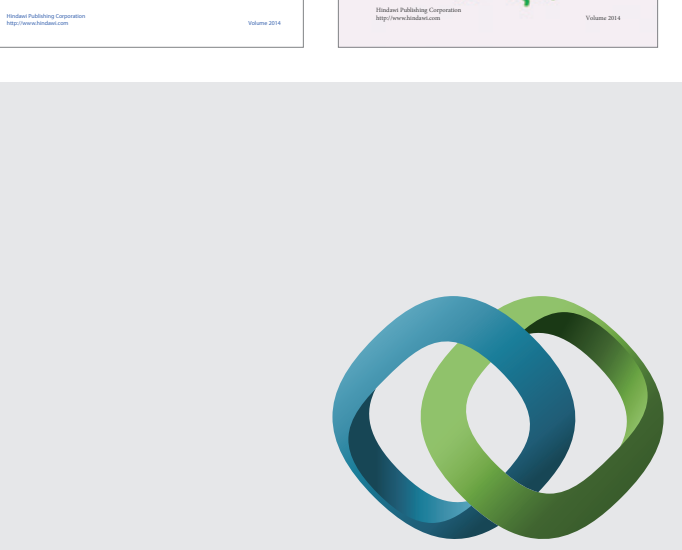

\section{Hindawi}

Submit your manuscripts at

http://www.hindawi.com
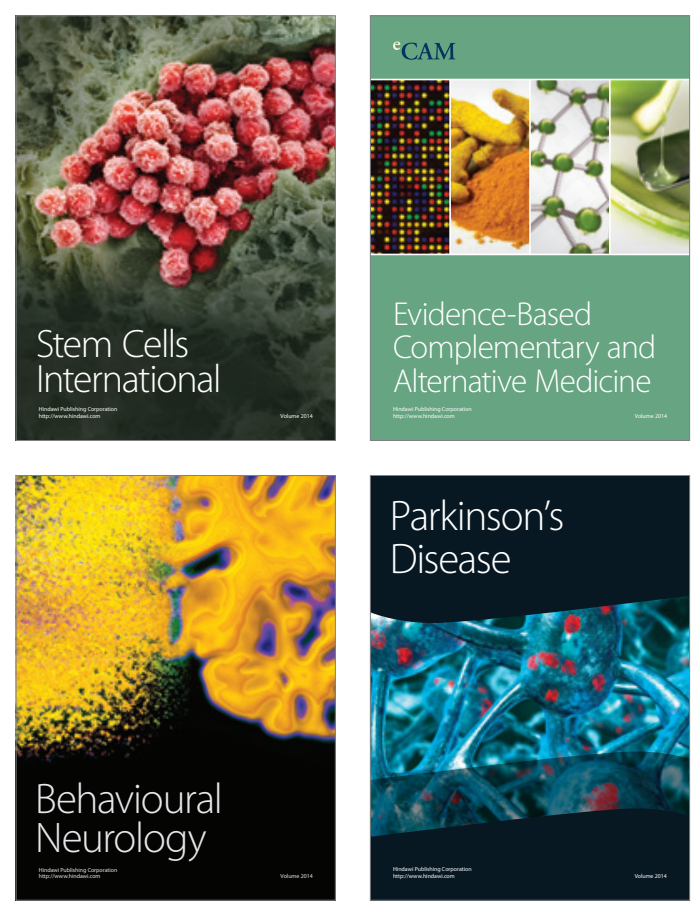

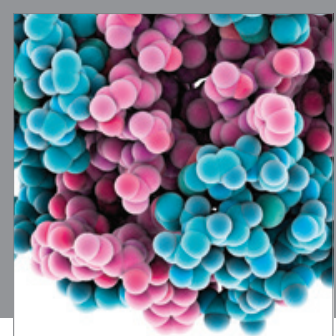

Journal of
Diabetes Research

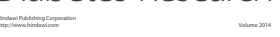

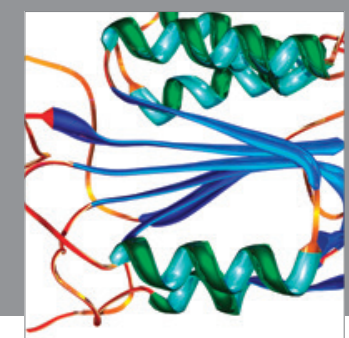

Disease Markers
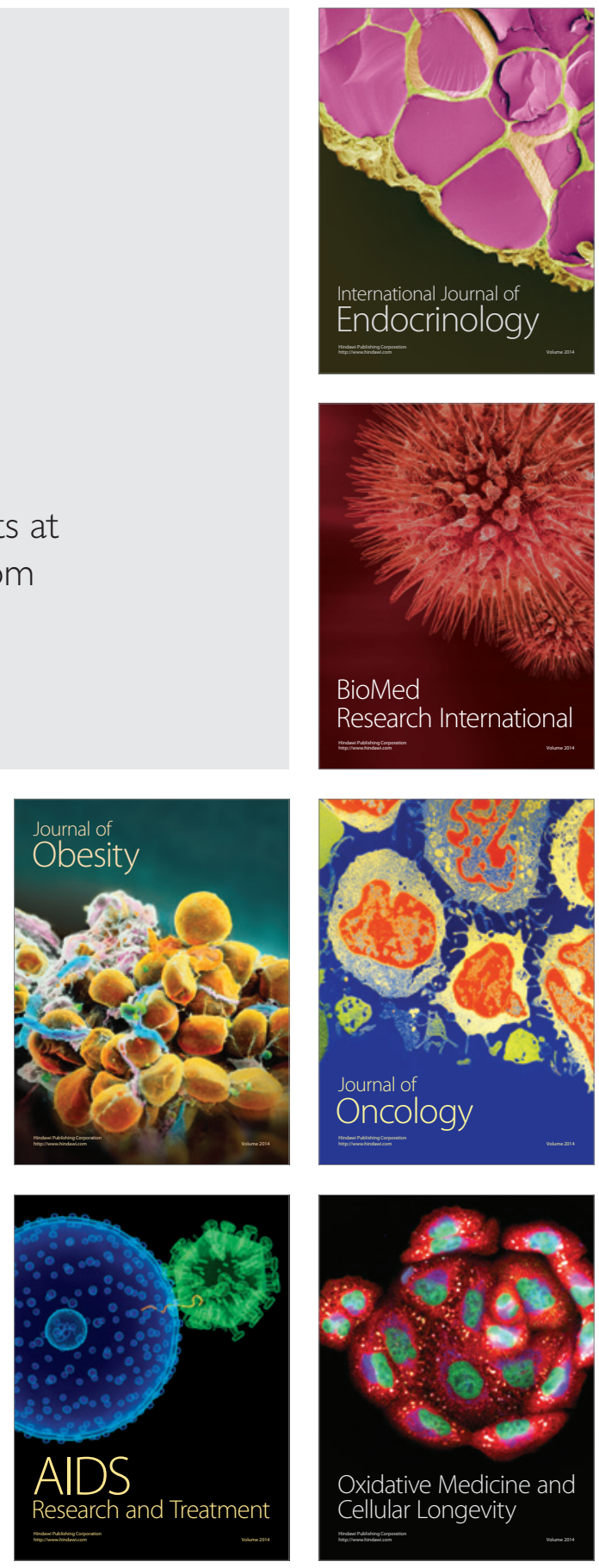